ВІСНИК

ОДЕСЬКОГО НАЦІОНАЛЬНОГО

МОРСЬКОГО УНІВЕРСИТЕТУ

№ 3 (60), 2019
HERALD

OF THE ODESSA NATIONAL

MARITIME UNIVERSITY

№ 3 (60), 2019

УДК 629.553

DOI 10.33082/2226-1893-2019-3-5-24

\author{
Г.В. Егоров \\ д.т.н., генеральный директор \\ В.И. Тонюк \\ технический директор \\ Морское Инженерное Бюро, г. Одесса, Украина
}

\title{
КОНЦЕПТ СУХОГРУЗНОГО МНОГОЦЕЛЕВОГО СУДНА ПРОЕКТА RSDЗ2М ТИПА «НАВИС» КЛАССА «АЗОВСКИЙ ПЯТИТЫСЯЧНИК»
}

Аннотация. Средний возраст судов класса «Волго-Балт» / «Сормовский» в настоящее время составляет более 30-35 лет, что вполне обуславливает настоятельную необходимость пополнения флота новыми судами с такой же речной грузоподъемностью - судами проекma RSD32M.

Кониепт является развитием проектов RSD18 (типа «UCF») $u$ RSD32, созданных Морским Инженерным Бюро в 2005-2006 годах, и «одноклассником» проекта RSD17 (типа «Мирзага Халилов») и судов типа «Валдай» и «Русич». Судно «южного» типа, поэтому выбор класса судна по району плавания (R2) и по ледовой категории (Ice1); применение люковых закрытий съемного типа с козловым судовым краном; среднеоборотные дизеля в качестве главных двигателей и ставшие уже классическими для этого типа судов полноповоротные винто-рулевые колонки с винтами фиксированного тага.

Выполнен детальный анализ основных характеристик, а также их сравнение с характеристиками судов-аналогов. Коэффичиент использования водоизмещения по дедвейту является наилучшим на всех рассмотренных осадках. Удельные показатели при других осадках проекта RSD32M лучше, чем у других судов аналогичного класса. При работе в портах Каспийского и Азовского морей проект RSD32M будет иметь экономические преимущества по сравнению со всеми другим судами.

Ключевые слова: водный транспорт, речные суда, суда смешанного река-море плавания, судостроение, проектирование, эффективность.

(C) Егоров Г.В., Тонюк В.И., 2019 
DOI 10.33082/2226-1893-2019-3-5-24

\author{
Г.В. Сгоров \\ д.т.н., генеральний директор \\ B.I. Тонюк \\ технічний директор \\ Морське Інженерне Бюро, м. Одеса, Украӥна
}

\title{
КОНЦЕПТ СУХОВАНТАЖНОГО БАГАТОЦІЛЬОВОГО СУДНА ПРОЕКТУ RSD32М ТИПУ «НАВІС» КЛАСУ «АЗОВСЬКИЙ П'ЯТИТИСЯЧНИК»
}

Анотація. Середній вік суден класу «Волго-Балт» / «Сормовський» в даний час складає більше за 30-35 років, що иілком обумовлює загальну необхідність поповнення флоту новими суднами з такою ж річковою вантажопідйомністю - суднами проекту RSD32M.

Кониепт є розвитком проектів RSD18 (mипу «UCF») $i$ RSD32, створених Морським Інженерним Бюро в 2005-2006 роках, $i$ «однокласником» проекту RSD17 (типу «Мірзага Халілов») і суден типу «Валдай» $i$ «Русич». Судно «південного» типу, тому вибір класу судна за районам плавання (R2) $i$ за льодовою категорію (Ice1); застосування люкових закриттів знімного типу з козловим судновим краном; середньооборотні дизеля в якості головних двигунів $і$ які вже стали класичними для ивого типу суден повноповоротні гвинто-рульові колонки з гвинтами фіксованого кроку.

Виконано детальний аналіз основних характеристик, а також їх порівняння з характеристиками суден-аналогів. Коефіцієнт використання водотоннажності за дедвейтом є найкращим на всіх розглянутих осадках. Питомі показники при інших осадках проекту RSD32M кращі, ніж на інших суднах аналогічного класу. При роботі в портах Каспійського і Азовського морів проект RSD32M матиме економічні переваги в порівнянні з усіма іншими суднами.

Ключові слова: водний транспорт, річкові судна, судна змішаного ріка-море плавання, суднобудування, проектування, ефективність.

UDC 629.553

DOI 10.33082/2226-1893-2019-3-5-24

\section{CONCEPT OF RSD32M DRY-CARGO MULTIPURPOSE VESSEL OF «NAVIS» TYPE OF «AZOV FIVE THOUSAND» CLASS}

\section{G.V. Yegorov}

Doctor of Technical Sciences, Professor, General Director

\section{V.I. Tonyuk}

Marine Engineering Bureau, Odessa, Ukraine 
Abstract. Mean age of "Volgo-Balt» / "Sormovsky» class vessels is now more than 30-35 years, that completely necessitates renewal of the fleet with new vessels with the same river cargo capacity - RSD32M project vessels.

The vessel have to transport 5000 tons of dry cargo, primarily grain, on $4.20 \mathrm{~m}$ draught at sea in the ports of Azov and Caspian Seas with guaranteed cargo capacity of 3000 tons in river to be no worse than "Omskiy» type vessels including draughts up to $3.20 \mathrm{~m}$.

The concept is a development of RSD18 ( $U U C F 》$ type) and RSD32 projects designed by Marine Engineering Bureau in 2005-2006, and the "classmate» of RSD17 project ("Mirzaga Khalilov» type), "Valdai» and "Rusich» type vessels. The vessel is of the "southern» type, therefore, choice of sailing navigation class of the vessel $-R 2$ and ice category - Icel; use of removable hatch covers with gantry ship crane; medium-speed diesel engines as the main engines, already became classic for this type of vessels fullyrotating rudder-propellers with fixed-pitch propellers. The purpose of RSD32M vessels is to transport general, bulk cargoes, packed and round timber, grain, scrap metal, bunches and rolls of metal, large-sized and heavy-lift cargoes, coal, dangerous goods of 1 2, 3, 4, 5, 6.1, 8, 9 classes of IMDG Code and cargoes of category $B$ of IMSBC Code. Sailing regions are internal waterways of European part of Russian Federation; Azov, Caspian, Black, Mediterranean Baltic, White, North Seas, including voyages around Europe and to Irish Sea in winter.

The detailed analysis of main characteristics and its comparison with characteristics of vessels-analogues are executed. Coefficient of displacement utilization by deadweight is the best on all reviewed draughts. Relative coefficients of RSD32M project on other draughts are better than on other vessels of the same class. In addition, energy consumption per unit of transport capacity on SCWL is on the same level of other new Marine Engineering Bureau projects. While operation in Caspian and Azov Seas RSD32M project will have economic advantages in comparison with all other vessels, hereat lightweight is smaller, building is less costly.

Keywords: water transport, river vessels, river-sea vessels, shipbuilding, design, efficiency.

Постановка проблемы. Классические представления о партионности грузов в море и в реке с учетом реальных путевых условий, по сути, полностью определяют главные параметры судна смешанного река-море плавания.

Ярким примером такого влияния условий являются сухогрузные суда проекта RSD32M. Судоходная компания - заказчик проекта исходила из того, что судно должно было перевозить 5000 тонн сухого груза, в первую очередь зерна, при осадке 4,20 м в море в портах Азовского и Каспийского морей при гарантированной грузоподъемности 3000 тонн в 
ВІСНИК

ОДЕСЬКОГО НАЦІОНАЛЬНОГО

МОРСЬКОГО УНІВЕРСИТЕТУ

№ 3 (60), 2019
HERALD

OF THE ODESSA NATIONAL

MARITIME UNIVERSITY

№ 3 (60), 2019

реке, чтобы в реке быть не хуже судов типа «Омский», в том числе при осадках до 3,20 м.

Всего на Окской судоверфи (см. рисунки 1-3) по заказу АО «ГТЛК» («Государственная лизинговая компания») в 2019 году было построено восемь судов этой серии.

Целью статьи является обоснование и описание создания технологически простого и экономически выгодного концепта для перевозки грузов в Азово-Черноморском и Каспийском регионах.

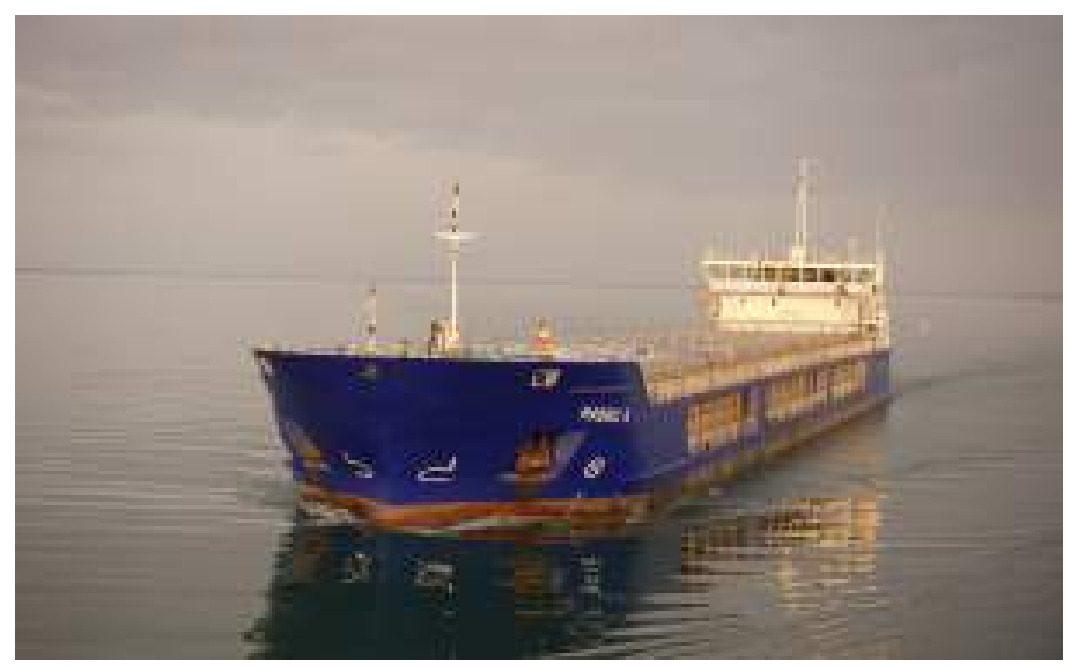

Pис. 1. Сухогрузное судно проекта RSD32М Навис-2 Автор фотографии - Сергей Мельников

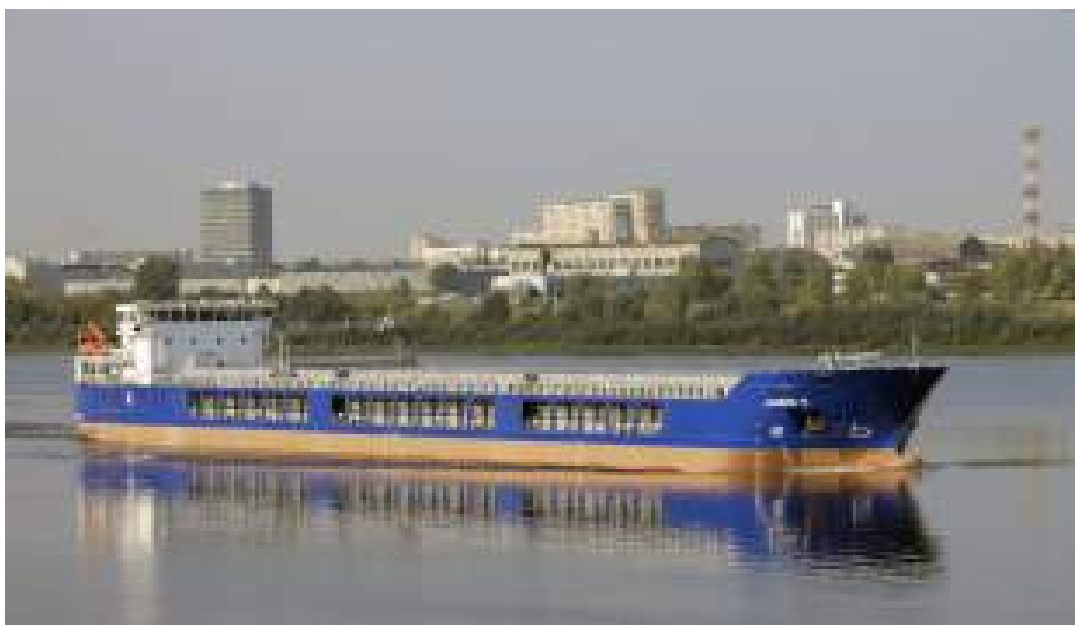

Puc. 2. Сухогрузное судно проекта RSD32M Навис-5 Автор фотографии - Михаил Элиан 


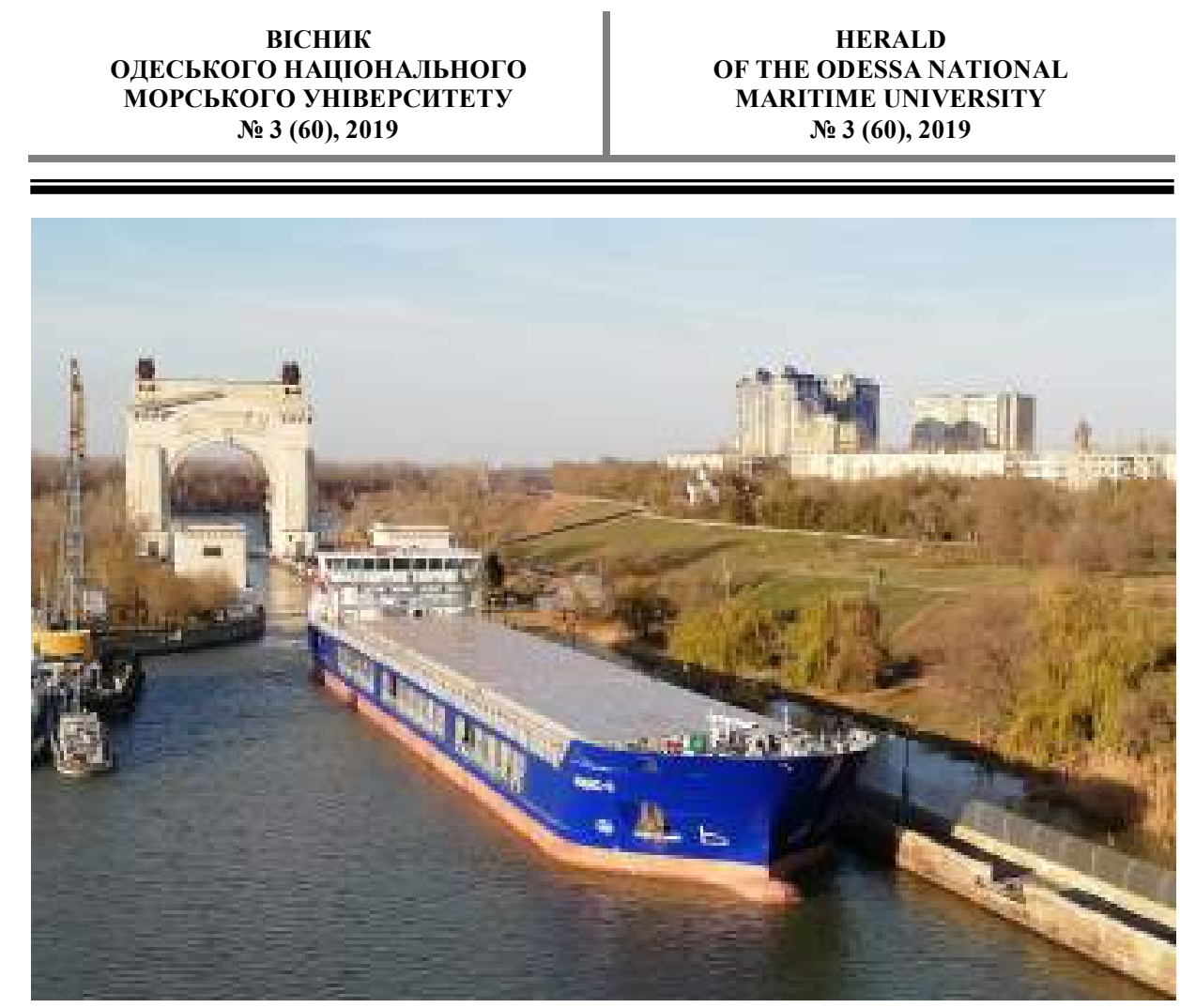

Puc. 3. Сухогрузное судно проекта RSD32M Навис-6.

Автор фотографии - Александр Рудков

Изложение основного материала. Суда проекта RSD32M в соответствии с принятой в Бюро классификацией [2] относятся к «азовским пятитысячникам», то есть, к классу азовско-каспийских «коастеров», которые имеют при характеристической в российских портах Азовского моря и портах Каспия (Астрахань, Нека) осадке 4,20-4,50 м грузоподъемность около 5000 тонн.

Является развитием проектов RSD18 (типа «UCF») и RSD32, созданных Морским Инженерным Бюро в 2005-2006 годах и «одноклассником» проекта RSD17 (типа «Мирзага Халилов») и судов типа «Валдай и «Русич».

Судно «южного» типа, поэтому выбор класса судна по району плавания (R2) и по ледовой категории (Ice1); применение люковых закрытий съемного типа с козловым судовым краном; среднеоборотные дизеля в качестве главных двигателей и ставшие уже классическими для этого типа судов полноповоротные винто-рулевые колонки с винтами фиксированного шага.

Назначение судов проекта RSD32M состоит в транспортировке генеральных, навалочных, лесных, зерновых и крупногабаритных грузов, контейнеров международного стандарта, опасных грузов классов 1, 2, 3, $4,5,6.1,8,9$ в соответствии с МК МПОГ и грузов категории «В» из МК МПНГ, угля. 
ВІСНИК

ОДЕСЬКОГО НАЦІОНАЛЬНОГО МОРСЬКОГО УНІВЕРСИТЕТУ № 3 (60), 2019
HERALD

OF THE ODESSA NATIONAL MARITIME UNIVERSITY № 3 (60), 2019

Эксплуатация предусматривается в Азовском, Черном, Средиземном, Каспийском, Балтийском, Белом, Северном морях, включая рейсы вокруг Европы зимой. Габариты позволяют судам эксплуатироваться также на внутренних водных путях (ВВП) Российской Федерации - через Волго-Донской и Волго-Балтийский каналы.

Суда могут работать на пониженных осадках в реке 3,20-3,40 м. Например, при осадке 3,20 м в пресной воде дедвейт составляет 3220 тонн, при 3,40 м - 3600 тонн, что позволило заказчику считать это проект в реке неким современным аналогом сухогрузных судов типа «Омский» (проектов 1743, 1743.1) и, соответственно, перспективной заменой многочисленных существующих судов проектов 1557, 614, 488A, 488AM2/3/4, 2-95, 2-95A/R, 92-13/040, 1743, 1743.1, 1743.3, 1743.7, 05074A, 791, столь популярных у частных судоходных компаний [3].

Проект судна разработан Морским Инженерным Бюро на класс PC KM Ice1 R2 AUT1-ICS BWM(T) CONT(deck, cargo holds Nos.1, 2, 3) DG(bulk, pack) и удовлетворяет всем требованиям международных конвенций, действующим на дату закладки соответствующих судов серии.

Архитектурно-конструктивный тип - стальной однопалубный, трехрюмный теплоход, с двумя полноповоротными винторулевыми колонками, с баком и ютом, с кормовым расположением жилой рубки и машинного отделения, с двойным дном и двойными бортами в районе грузовых трюмов, с бульбовой носовой и транцевой кормовой оконечностями, с люковыми закрытиями съемного типа, с носовым подруливающим устройством (см. рисунок 4).

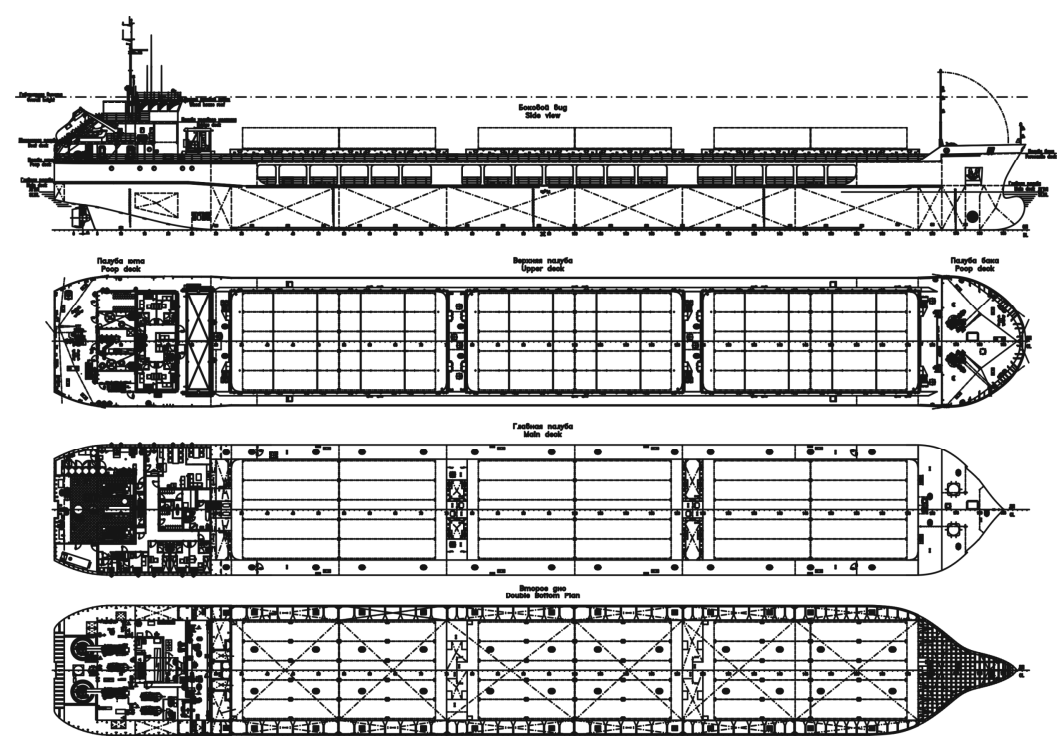

Рис. 4. Общее расположение судна проекта RSD32M 
В носовой оконечности расположены форпик, шахта лага и эхолота, шкиперская, малярная, общесудовая кладовая, а также носовое подруливающее устройство типа «винт в трубе» мощностью 120 кВт.

В кормовой оконечности судна расположены МО, надстройка юта и трехъярусная рубка со служебными и жилыми помещениями для экипажа численностью 11 человек (14 мест). Ходовой мостик выполнен с круговым обзором и минимальными зонами затенения.

В соответствии с рекомендациями [1] применение продольной системы набора палубы, бортов и днища в средней части в сочетании с увеличением поперечной шпации и одновременном уменьшении шпации продольного набора обеспечило более полное участие пластин корпуса в общем изгибе и лучшее восприятие локальных нагрузок при швартовках, сохранение приемлемого внешнего вида.

Мидель-шпангоут судна приведен на рисунке 5.

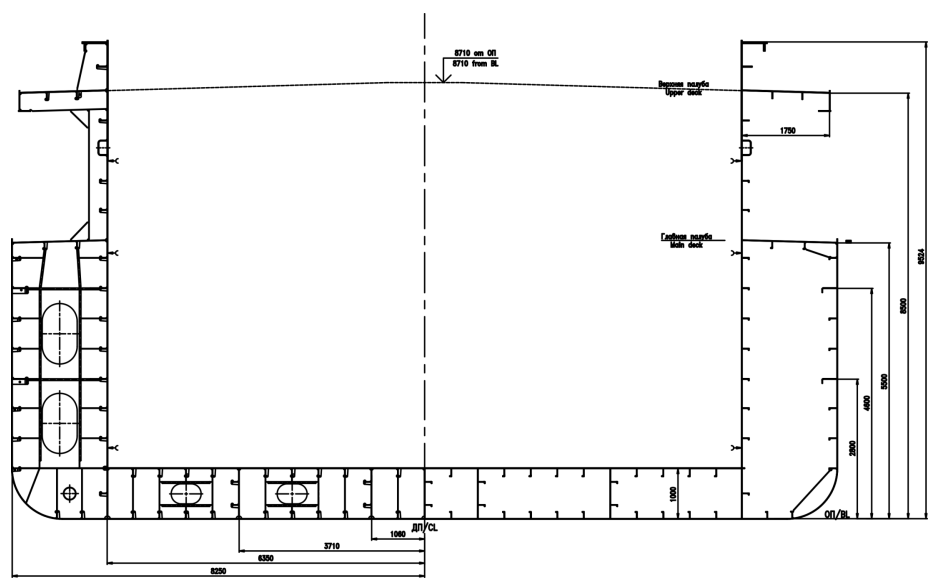

Puс. 5. Мидель-шпангоут судна проекта RSD32M

Tрюма, как и на прототипах RS18 и RSD32, выполнены ящичной формы, гладкостенными, удобными для проведения грузовых работ и размещения груза без штивки (см. рисунок 6). Размеры грузовых трюмов одинаковые - 27,30 х 12,68 x 8,54 м. Высота трюма гарантирует размещение трех ярусов контейнеров международного стандарта высотой до 8,5 футов.

Суда получили съемные люковые закрытия типа «Lift Away», впервые примененные в отечественной практике на судах проекта 005RSD03 типа «Карелия» [5] и 003RSD04 типа «Каспиан Экспресс». Открытие и закрытие секций осуществляется при помощи козлового крана, расположенного «по-походному» у носовой переборки жилой рубки. Одной из особенностей данного типа люковых закрытий является возможность открытия трюма в любом месте путем подъема соответствующей секции закрытия. 
ВІСНИК

ОДЕСЬКОГО НАЦІОНАЛЬНОГО

МОРСЬКОГО УНІВЕРСИТЕТУ № 3 (60), 2019
HERALD

OF THE ODESSA NATIONAL MARITIME UNIVERSITY № 3 (60), 2019

RSD18

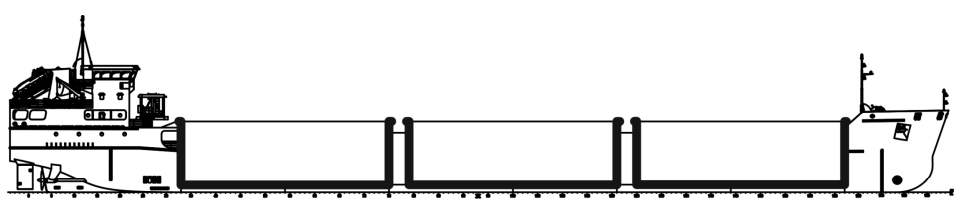

RSD32

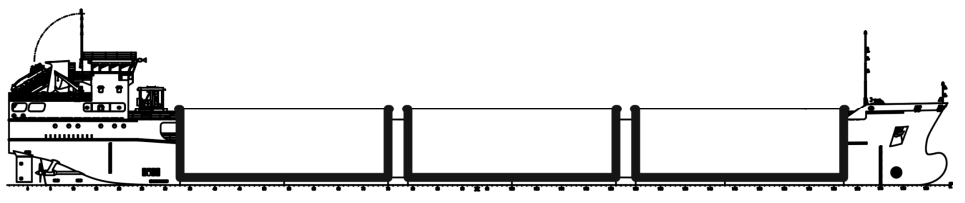

RSD32M

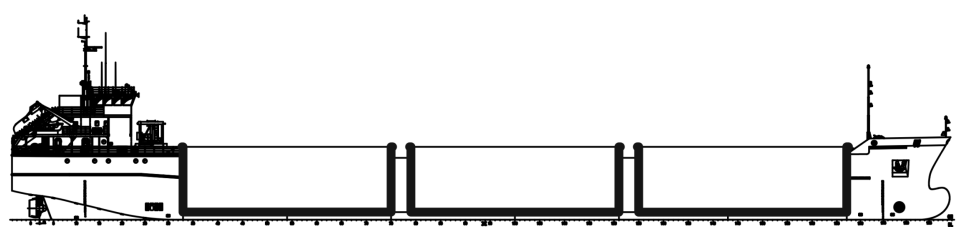

RSD18

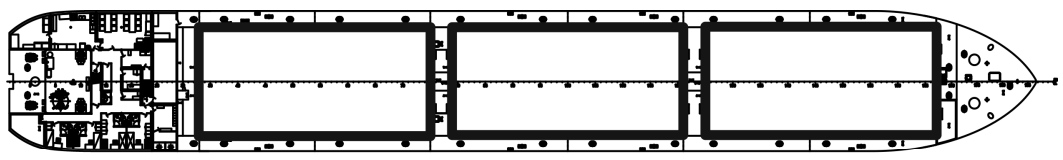

RSD32

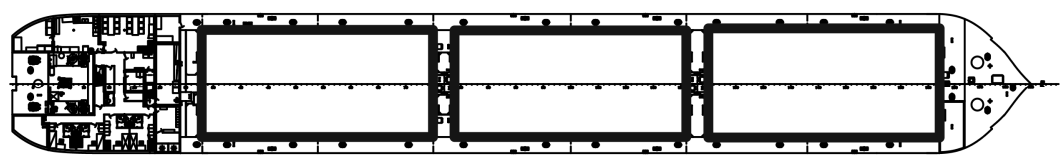

RSD32M

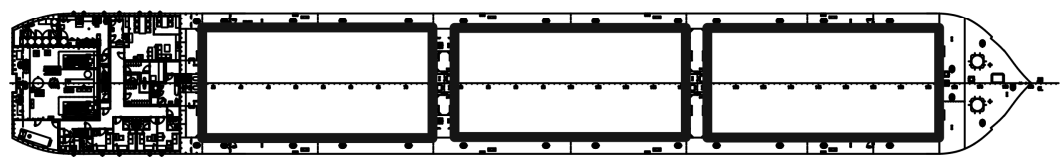

Рис. 6. Сравнение грузовых трюмов сухогрузных судов проектов RSD18, RSD32 и RSD32M

Расчетная нагрузка на люковые крышки составляет 3,50 т/м² (трюм 1) и 2,60 т/м² (трюма 2 и 3), что соответствует требованиям Международной Конвенции о грузовой марке и дает возможность размещения на них каравана лесных грузов высотой 2,5 м или одного яруса контейнеров максимальной массы.

На палубе разрешаются к перевозке в упаковке опасные грузы классов $1,2,3,4.1,4.2,5,6.1,8$ и 9, которые можно тушить водой. В трюмах - опасные грузы классов $1.4 \mathrm{~S}, 2.1,2.2,2.3$ (невоспламеняющиеся), 3 , $4.1,4.2,4.3$ (кроме жидкостей с температурой вспышки менее $23^{\circ} \mathrm{C}$ ), 5.1 , $6.1,8$ и 9 . 
В трюмах навалом могут перевозиться опасные грузы классов 4.1, 4.2, 5.1 и 9, а также грузы ВОН, в том числе:

1. Бурый уголь, брикеты;

2. Пирит обожженный;

3. Древесный уголь;

4. Уголь;

5. Железо прямого восстановления (В);

6. Железо прямого восстановления (А), брикеты горячепрессованные;

7. Железо прямого восстановления (C);

8. Феррофосфор (включая брикеты);

9. Ферросилиций, содержащий 25-30 \% кремния или $\geq 90 \%$ (включая брикеты);

10. Плавиковый шпат;

11. Известь (негашеная);

12. Семена хлопчатника, содержащие линт;

13. Оксид магния (негашенный);

14. Металлические сернистые концентраты;

15. Торфяной мох (торф);

16. Нефтяной кокс, обожженный или необожженный;

17. Пек комовый;

18. Древесные опилки;

19. Силикомарганец (низкоуглеродистый);

20. Мясокостная мука (отбросы органические);

21. Руда ванадиевая;

22. Древесная щепа;

23. Древесные окатыши, содержащие добавки и/или связующие вещества;

24. Древесные окатыши, не содержащие добавок и/или связующих веществ;

25. Лесоматериалы обыкновенные;

26. Алюминия гидрат;

27. Алюминия побочные продукты плавки/ переплавки, обработанные;

28. Клинкерный шлак;

29. Каменноугольный пек;

30. Никелевый штейн в гранулах (влагосодержанием менее $2 \%$ );

31. Твердое топливо, продукт вторичной переработки бумаги и пластмасс;

32. Древесина обожженная;

33. Силикат натрия в аморфных комках;

34. Борная кислота. 
ВІСНИК

ОДЕСЬКОГО НАЦІОНАЛЬНОГО МОРСЬКОГО УНІВЕРСИТЕТУ № 3 (60), 2019
HERALD

OF THE ODESSA NATIONAL

MARITIME UNIVERSITY № $3(60), 2019$

Теоретический корпус судна (см. рисунок 7), полученный с помощью современных методов CFD-моделирования на основе создания параметрической трехмерной модели поверхности, имеет цилиндрическую вставку протяженностью $0,639 L$, коэффициент общей полноты при осадке 4,20 м - 0,866, коэффициент полноты ЛГВЛ - 0,943, при осадке 3,60 м $-0,852$ и 0,937 соответственно.

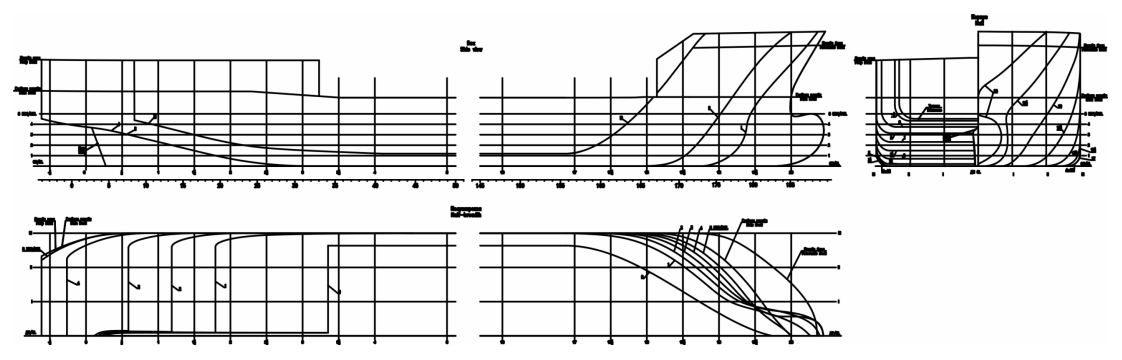

Puс. 7. Теоретический корпуса судна проекта RSD32M 880 мин $^{-1}$.

На испытаниях судно показало скорость 11,7 узла при оборотах

Движение и управляемость судна обеспечивается двумя кормовыми полноповоротными винто-рулевыми колонками (ВРК) с винтами фиксированного шага диаметром 1900 мм в насадках (см. рисунок 8). Привод к ВРК от главных дизелей осуществляется через механическую $\mathrm{Z}$-передачу. Замена обычной пропульсии, которая ранее использовалась на RSD18 и RSD32, на ВРК была осуществлена Заказчиком с целью снижения трудоемкости и стоимости постройки и увеличения маневренных свойств судна.

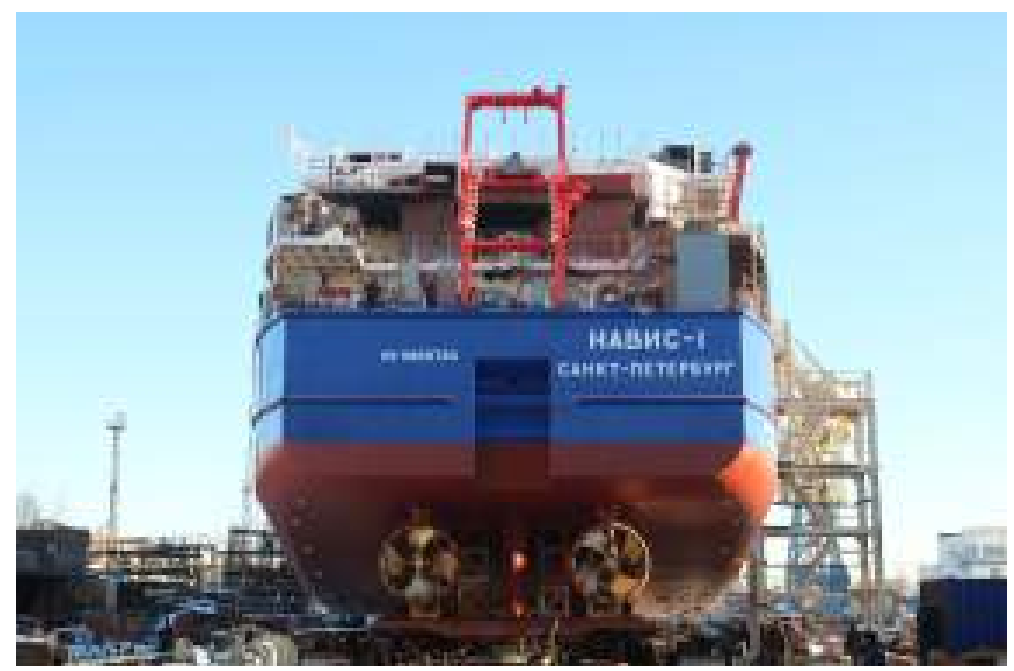

Puc. 8. ВРК судна проекта RSD32M 
ВІСНИК

ОДЕСЬКОГО НАЦІОНАЛЬНОГО

МОРСЬКОГО УНІВЕРСИТЕТУ

№ 3 (60), 2019
HERALD

OF THE ODESSA NATIONAL

MARITIME UNIVERSITY № 3 (60), 2019

Испытания, проведенные компанией «Астра НН» [6], показали прекрасную управляемость судна с ВРК - см. таблицу 1. Диаграмма циркуляции судна при перекладке ВРК на 30 градусов на переднем ходу во время испытаний в балласте приведена на рисунке 9. Тактический диаметр циркуляции составил 1,5 длины судна при нормативе 5. При активном торможении судно останавливалось с полного хода в 11,7 узлов за 425 метров (3,45 длины - при нормативе 15) и 198 секунд.

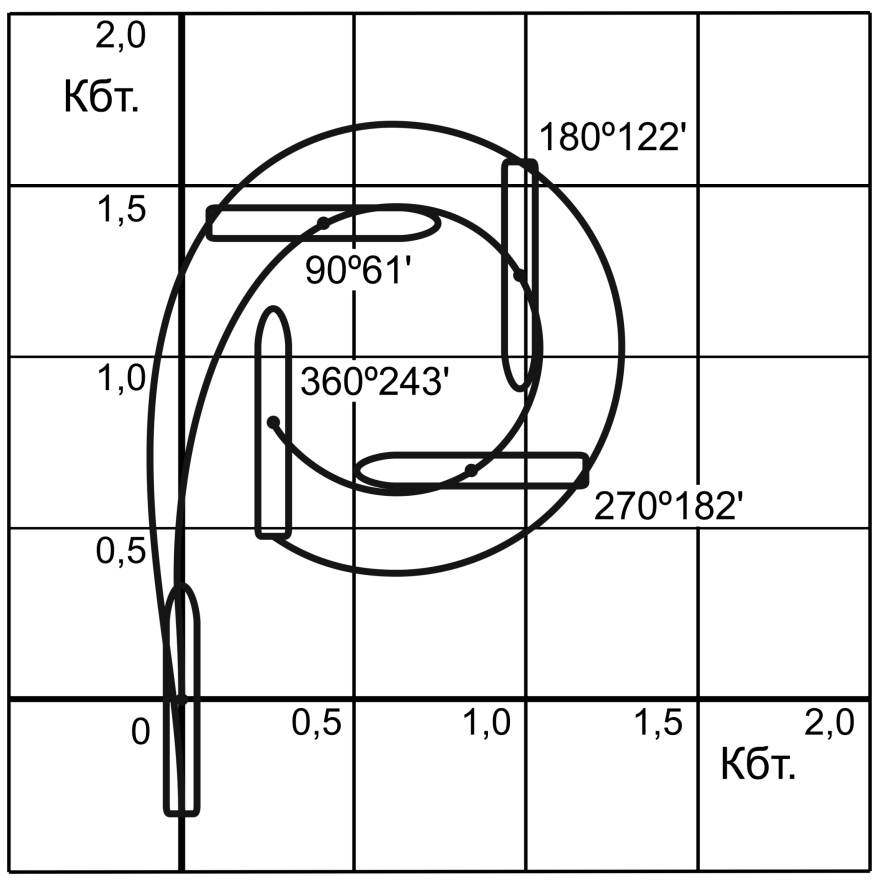

Рис. 9. Диаграмма циркуляции судна при перекладке ВРК на $30^{\circ}$ на переднем ходу во время испытаний в балласте

Корпус судна был подкреплен на ледовую категорию Ice1, который предполагает круглогодичное плавание в незамерзающих морях, в мелкобитом разреженном льду неарктических морей (эпизодическое самостоятельное плавание в мелкобитом разреженном льду толщиной 0,40 м со скоростью 5 узлов; плавание в канале за ледоколом в сплошном льду толщиной 0,35 м со скоростью 3 узла); а также работу в условиях продленной навигации в реках соответственно ледовому классу Icel при температуре наружного воздуха минус $23{ }^{\circ} \mathrm{C}$. Расчетная температура наружного воздуха $35{ }^{\circ} \mathrm{C}$ при влажности $65 \%$ летом и $-25{ }^{\circ} \mathrm{C}$ при влажности $85 \%$ зимой, воды от $32{ }^{\circ} \mathrm{C}$ до $0{ }^{\circ} \mathrm{C}$ соответственно.

Выбранная ледовая категория обеспечивает зимнюю эксплуатацию в Азовском и Каспийском морях. 
ВІСНИК

ОДЕСЬКОГО НАЦІОНАЛЬНОГО

МОРСЬКОГО УНІВЕРСИТЕТУ

№ 3 (60), 2019
HERALD

OF THE ODESSA NATIONAL

MARITIME UNIVERSITY

№ 3 (60), 2019

Таблийа 1

Параметры маневренности, определенные в ходе испытаний судна в балласте и пересчитанные на состояние «в грузу»

\begin{tabular}{|c|c|c|c|}
\hline $\begin{array}{c}\text { Параметр } \\
\text { маневренности }\end{array}$ & Размерность & $\begin{array}{c}\text { Получено } \\
\text { при испытаниях }\end{array}$ & Критерий ИМО \\
\hline \multicolumn{4}{|c|}{ Циркуляция судна при угле перекладки рулей $35^{\circ}$} \\
\hline Время полной циркуляции & Мин-сек & $3-55$ & Не нормируется \\
\hline Диаметр циркуляции & Длина судна & 1,2 & Не нормируется \\
\hline Выдвиг & Длина судна & 2,2 & 4,5 \\
\hline $\begin{array}{l}\text { Тактический диаметр } \\
\text { циркуляции }\end{array}$ & Длина судна & 1,5 & 5,0 \\
\hline \multicolumn{4}{|c|}{ Маневр «зигзаг» $10^{\circ}-10^{\circ}$ ПБ/ЛБ } \\
\hline Первый угол зарыскивания & Град. & 5,8 & 16,1 \\
\hline Второй угол зарыскивания & Град. & 5,6 & 34,2 \\
\hline \multicolumn{4}{|c|}{ Маневр «зигзаг» $20^{\circ}-20^{\circ}$ ПБ/ЛБ } \\
\hline Первый угол зарыскивания & Град. & 17,1 & 25 \\
\hline Второй угол зарыскивания & Град. & 22,8 & Не нормируется \\
\hline \multicolumn{4}{|c|}{ Тормозной путь } \\
\hline Пройденный путь & Длина судна & 4,27 & 15 \\
\hline \multicolumn{4}{|c|}{ Начальная поворотливость при угле перекладки рулей $10^{\circ}-10^{\circ}$} \\
\hline $\begin{array}{l}\text { Пройденный путь } \\
\text { с момента перекладки рулей }\end{array}$ & Длина судна & 0,95 & 2,5 \\
\hline \multicolumn{4}{|c|}{$\begin{array}{c}\text { Циркуляция судна при угле перекладки рулевых органов } 30^{\circ} \text { на мелководье } \\
\text { при } T / H=0,7\end{array}$} \\
\hline Время полной циркуляции & Мин-сек & $6-18$ & Не нормируется \\
\hline Диаметр циркуляции & Длина судна & 1,7 & Не нормируется \\
\hline Выдвиг & Длина судна & 3,6 & 4,5 \\
\hline $\begin{array}{l}\text { Тактический диаметр } \\
\text { циркуляции }\end{array}$ & Длина судна & 2,4 & 5,0 \\
\hline
\end{tabular}

Источник: ООО «Астра - НН»

В качестве материала основных конструкций корпуса применяется судостроительная сталь категорий D36, A36, D32, D и А. Верхняя часть непрерывных продольных комингсов люков и верхняя палуба выполнены из судостроительной стали категории D36 с пределом текучести 355 МПа. Элементы конструкций палуб бака и юта, жилая надстройка - из стали категории А. 
Корпус имеет двойное дно, двойные борта, главную и верхнюю палубы с шириной раскрытия $0,77 \mathrm{~B}$, непрерывные продольные комингсы грузовых люков высотой 4 м (от главной палубы). Высота двойного дна 1000 м, ширина бортовых цистерн 1900 мм.

Продольные комингсы грузового трюма установлены в плоскости продольных переборок трюма. За счет применения высоких непрерывных комингсов люков с прочным палубным стрингером комингса люка, расположенным на высоте 3,0 м над главной палубой и переходящим в носу в палубу бака с уступом высотой 1,0 м, а в районе машинного отделения в палубу юта, удалость обеспечить повышение стандарта общей прочности при увеличении грузоподъемности в море и грузовместимости.

Поперечные переборки выполнены плоские. Верхняя и главная палубы, днище и второе дно, борт и второй борт выполняются по продольной системе набора, в оконечностях и машинном отделении - по поперечной системе набора.

Поперечная шпация: в районе шп. 167...29 - 650 мм, в районе корма...29 шп. и шп. 167...нос - 600 мм. Шпация продольного набора - 530, 600 и 650 мм. Шпация поперечного рамного набора в средней части 1950 мм.

Двойное дно рассчитано на интенсивность распределенной нагрузки $10 \mathrm{~T} / \mathrm{m}^{2}$, а также на работу грейфером.

Исходя из результатов расчетного определения сопротивления судна, в состав главной энергетической установки включены два среднеоборотных дизеля максимальной длительной мощностью 1100 кВт при частоте 880 мин $^{-1}$, работающих на 2 полноповоротные винторулевые колонки с винтами фиксированного шага в пропульсивной насадке;

Запасы топлива размещаются в диптанках в районе носовой переборки МО. Автономность судна по запасам топлива, воды и провизии 20 суток для морских условий и 15 суток при плавании по реке. Дальность плавания - 4000 миль.

Электроэнергетическая установка сухогруза состоит из трех дизель-генераторов (ДГ) мощностью по 160 кВт каждый и одного аварийного дизель-генератора (АДГ) мощностью 90 кВт. Приводные двигатели генераторов работают на дизельном топлив.

Предусмотрены следующие эксплуатационные режимы работы электростанции:

- ходовой - работает 2 ДГ х 160 кВт, резерв - 1 ДГ х 160 кВт;

2 ДГ х 160 кВт;

- тушение пожара - работает 1 ДГ х 160 кВт, резерв -

- маневры - работает 2 ДГ х 160 кВт

- стоянка - работает 1 ДГ х 160 кВт, резерв - 2 ДГ х 160 кВт;

- аварийный - работает 1 АДГ х 90 кВт. 
Судовые устройства обеспечивают выполнение всех требований надзорных органов к судам данного типа.

Спуск и подъем носовых и кормового якорей выполняется якорношвартовными лебедками. Судно снабжается двумя носовыми становыми якорями Холла массой 2500 кг каждый и одним кормовым якорем Холла массой 1750 кг. Якоря убираются в клюзы с нишами и откидными крышками.

В качестве спасательных средств используется спасательная свободнопадающая шлюпка вместимостью 14 человек, спускаемая устройством гравитационного типа с гидравлической шлюпочной лебедкой, как методом свободного падения, так и контролируемым спуском, а также два плота вместимостью по 16 человек каждый. Плот, установленный по правому борту на шлюпочной палубе, спускаемого типа. Кроме того, на судне в районе носовой оконечности установлен сбрасываемый плот вместимостью 6 человек. На шлюпочной палубе по ПрБ установлена дежурная шлюпка вместимостью 6 человек. Подъем и спуск дежурной шлюпки и спускаемого плота осуществляется краном.

Состав средств связи предусмотрен в объеме требований Глобальной морской системы связи при бедствии и для обеспечения безопасности (ГМССБ) для морских районов $\mathrm{A} 1+\mathrm{A} 2+\mathrm{A} 3$. Комплекс современного судового радиооборудования обеспечивает связь при бедствиях и безопасность мореплавания, а также эксплуатационную связь общего назначения.

Гирокомпас с репитерами, главный магнитный компас, лаг, эхолот, приемоиндикатор GPS, две радиолокационные станции, а также АИС обеспечивают судоводителя и системы-потребители навигационной информацией.

Для приема и выдачи балласта на судне имеется балластно-осушительная система, обслуживаемая двумя электроприводными центробежными насосами. В соответствии с международными требованиями, на судне предусмотрена обработка балласта при помощи системы управления балластными водами.

С целью объединения систем управления и контроля на судне предусмотрена интегрированная автоматизированная система управления (далее ИАСУ) с выполнением требований класса PC AUT1-ICS.

ИАСУ построена на основе компьютерной сети объединяющей в единое целое следующие элементы подсистем: система контроля и управления пропульсивным комплексом; система автоматизации судовых дизельных двигателей; система автоматизации электростанции; система автоматизации судовых систем; система аварийно-предупредительной сигнализации (АПС). 
Структура системы ИАСУ основывается на принципе распределенной конфигурации. Компьютерная сеть системы обеспечивает связь между операторскими станциями и блоками сбора и управления, расположенными в непосредственной близости к объекту управления. Резервирование сети и функций системы обеспечивается с помощью дублированной сети и сетевого оборудования, которое в случае выхода из строя одного канала связи обеспечивает направление сигналов по оставшемуся каналу.

Для размещения экипажа численностью 11 человек, предназначаются 3 одноместные блок-каюты и 8 одноместных кают с санузлом и душем, каюта для лоцмана. В трех одноместных каютах имеется по одному резервному месту. Общее число мест (включая 3 резервных) - 14 .

Как известно, среди сухогрузных судов смешанного река-море плавания особое положение [4] занимают суда проектов 1557, 614, 488A, 488AM2/3/4，2-95，2-95A/R，92-13/040，1743，1743.1，1743.3，1743.7, 05074A, 791 грузоподъемностью в реке при осадках 3,40-3,60 м около 3000 т. Они составляют примерно $60 \%$ от общего числа судов подобного назначения и являются основным транспортным средством значительной части российских судоходных компаний. Особая роль этих судов состоит в том, что грузоподъемность 3000 т соответствует исторически сложившейся на отечественном рынке партионности, равной массе груза, перевозимого одним железнодорожным составом в 50-52 вагона. Это обстоятельство позволяет транспортировать массовые грузы из речных портов России в порты Европы и Средиземного моря без промежуточного хранения на складах порта и, соответственно, без дополнительных расходов на перегрузку и хранение.

Принципиальным отличием работы судов данного класса в современных экономических условиях является интенсивная эксплуатация в осенне-зимний период из морских портов, где проходные осадки больше, чем в реке, что позволяет увеличить морскую грузоподъемность до уровня, соответствующего минимальному надводному борту по требованиям Международной Конвенции о грузовой марке.

Средний возраст судов класса «Волго-Балт» / «Сормовский» в настоящее время составляет более 30-35 лет, что вполне обуславливает настоятельную необходимость пополнения флота новыми судами с такой же речной грузоподъемностью - судами проекта RSD32M.

При этом на типичных в азовских портах осадках около 4,2 м суда проекта RSD32M будут заменой для широко известных серий судов грузоподъемностью около 5000 тонн типа «Волго-Дон» / «Волжский», средний возраст которых также перевалил за 30-35 лет.

Именно для такой цели Заказчик проекта предполагал применять сухогрузные суда проекта RSD32M. 
Однако в действительности эти суда сегодня используются как каспийские с характеристической в портах Каспия (Астрахань, Оля, Махачкала, Нека) грузоподъемностью около 5000 т, с возможностью перевозки грузов (при неполной грузоподъемности) по Волго-Донскому судоходному каналу (ВДСК).

Поэтому представляет интерес сопоставление технико-эксплуатационных характеристик судна проекта RSD32M с соответствующими характеристиками каспийских и наиболее близких к ним судов-аналогов судов типа «Кишинев» (пр. 1572), судов типа «Василий Шукшин» (пр. 1588) и судов типа «Русич» (пр. 00101), а также новых судов проектов RSD18 типа «UCF» и RSD17 типа «Мирзага Халилов».

Согласно данным таблицы 2 коэффициент использования водоизмещения по дедвейту является наилучшим на всех рассмотренных осадках (как в море, так и в пресной воде), кроме проекта RSD17 типа «Мирзага Халилов» при осадке по ЛГВЛ - за счет бо́льшей осадки по ЛГВЛ. При этом энергозатраты на единицу транспортной производительности при осадке по ЛГВЛ находятся на уровне других новых проектов Морского Инженерного Бюро.

В целом, удельные показатели при других осадках проекта RSD32M лучше, чем у других судов аналогичного класса, например, y проекта RSD18 типа «UCF», который также сейчас применяется как «каспийский» сухогруз. Таким образом, при работе в портах Каспийского моря (иранские и туркменские порты - осадка 4,5 м) проект RSD32M будет иметь экономические преимущества по сравнению со всеми другим судами.

При работе в море при осадке 4,20 м и в пресной воде с осадками 4,00 м и менее суда проекта RSD32M превосходят по дедвейту все суда класса «азовских пятитысячников», и при этом они меньше по массе корпуса и поэтому дешевле в постройке (что собственно и было поставлено, как проектная «сверхзадача»).

Заключение. Таким образом, был создан концепт сухогрузного судна, который перевозит 5000 тонн груза, в первую очередь зерна, при осадке 4,20 м в море (порты Азовского и Каспийского морей) при гарантированной грузоподъемности 3000 тонн в реке (в реке, как аналог судов типа «Омский», в том числе при осадках до 3,20 м). 


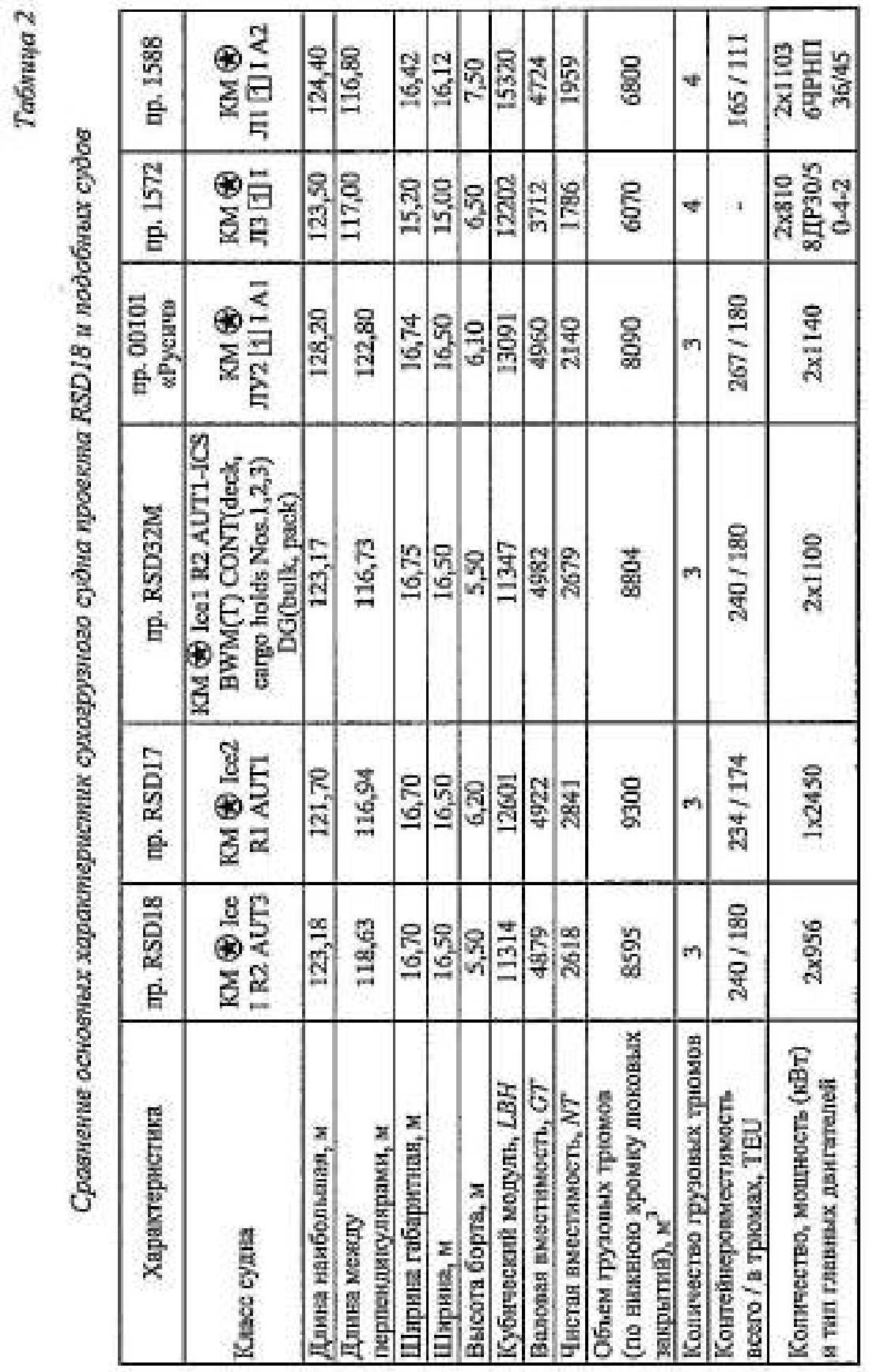




\begin{tabular}{|c|c|c|c|c|c|c|c|c|c|c|c|}
\hline 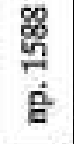 & वे & 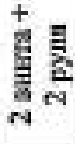 & $\frac{\sqrt{6}}{\frac{x}{m}}$ & ' & . & 유 & 28 & $\$$ & $\underset{1}{-1}$ & 恕 & ్ㅕㅇ \\
\hline$\frac{\mathrm{N}}{\mathrm{c}}$ & 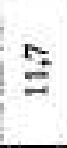 & 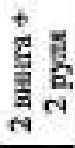 & 㷇 & - & . & శ్య & $\frac{\vec{n}}{\mathrm{n}}$ & $\underset{\nabla}{2}$ & म्) & \& & 응 \\
\hline 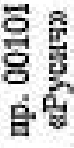 & $\stackrel{9}{=}$ & 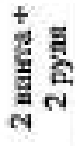 & $\frac{\sqrt[్]{7}}{\sqrt[x]{7}}$ & $\underline{\underline{z}}$ & $\underline{8}$ & त्र & 희 & 7 & $\stackrel{5}{=}$ & 多 & 骂 \\
\hline 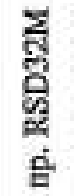 & $=$ & 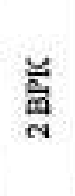 & $\frac{8}{7}$ & $\stackrel{8}{8}$ & ని & त्षि & $\exists$ & $\frac{7}{8}$ & $\underline{E}$ & 胥 & 형 \\
\hline 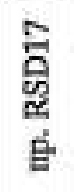 & 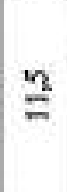 & $\begin{array}{l}\text { 总 } \\
\stackrel{+}{+} \\
\text { 렬 } \\
\text { 总 }\end{array}$ & 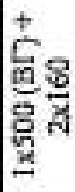 & 总竞 & \$్లి & तิ & 회용 & นุ & $\stackrel{7}{2}$ & 总 & 8 \\
\hline 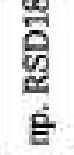 & $\stackrel{9}{=}$ & 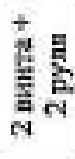 & 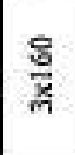 & 品 & నิ & ন্ & 원 & 6 & $\stackrel{9}{=}$ & $\frac{\mathbb{2}}{\delta}$ & 형 \\
\hline 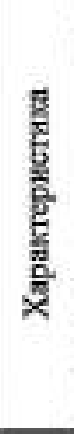 & 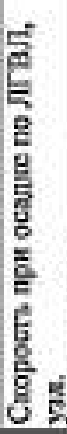 & 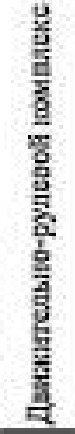 & 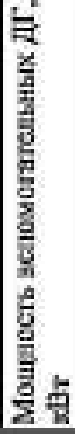 & 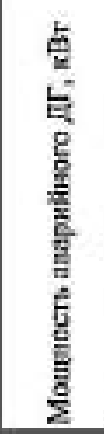 & 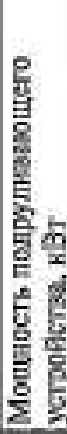 & 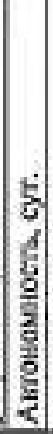 & 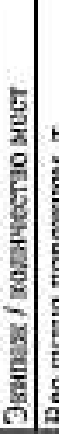 & 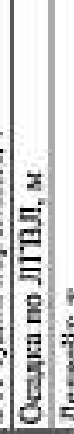 & 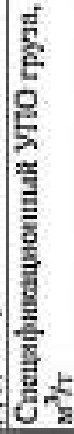 & 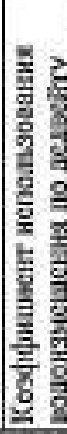 & 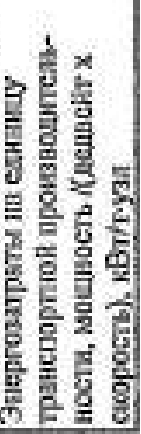 \\
\hline
\end{tabular}




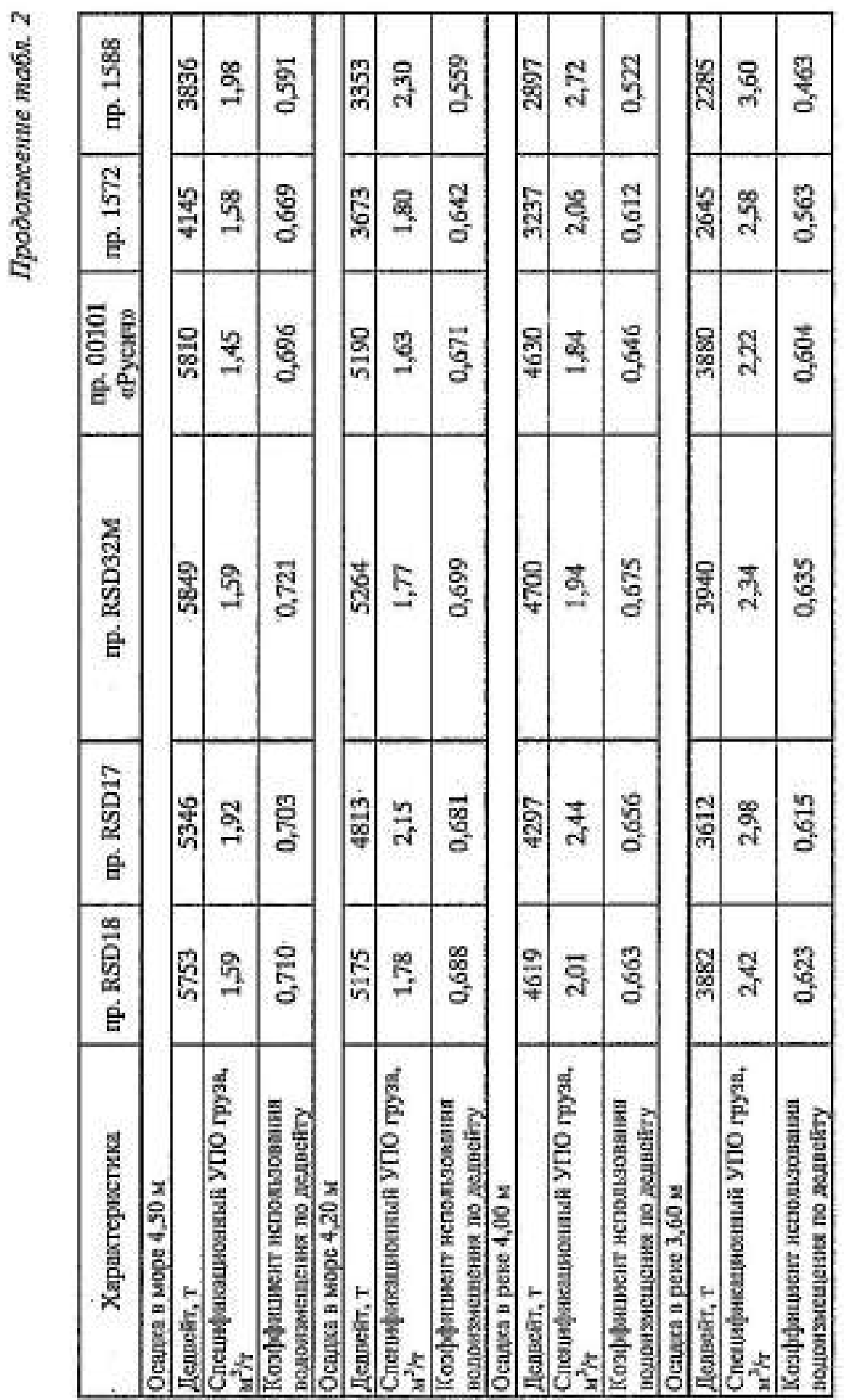


ВІСНИК

ОДЕСЬКОГО НАЦІОНАЛЬНОГО

МОРСЬКОГО УНІВЕРСИТЕТУ

№ 3 (60), 2019
HERALD

OF THE ODESSA NATIONAL

MARITIME UNIVERSITY

№ 3 (60), 2019

\section{ЛІТЕРАТУРА}

1. Егоров Г.В. Проектирование судов ограниченных районов плавания на основании теории риска. СПб.: Судостроение, 2007. 384 c.

2. Егоров Г.В. Обновленная линейка многочелевых сухогрузных судов смешанного плавания и коастеров Морского Инженерного Бюро // Морская Биржа. 2011. № 3 (37). С. 38-42.

3. Егоров Г.В. Сухогрузные суда смешанного плавания. Перспективы существующего флота // Проблемы техники. 2012. №2. С. 3-21.

4. Егоров Г.В. Сухогрузные суда в экономики России ХХІ века // Морская Биржа. 2012. № 4 (42). С. 24-34.

5. Егоров Г.В., Тонюк В.И. Двенадияать многоичелевых сухогрузных судов дедвейтом 5500 тонн проекта 005RSD03 типа «Россиянин» // Судостроение. 2015. № 1 С. 9-17.

6. RSD32-2019-507.Формуляр маневренных характеристик головного сухогрузного судна «НАВИС-1» проекта RSD32M. Нижний Новгород, Астра - НН, 2019. 44 c.

\section{REFERENCE}

1. Egorov G.V. (2007). Proyektirovaniye sudov ogranichennykh rayonov plavaniya na osnovanii teorii riska [Design of restricted area of operation ships based on risk theory]. Sudostroenie (Shipbuilding), 384 p. [in Russian].

2. Egorov G.V. (2011). Obnovlennaya lineyka mnogotselevykh sukhogruznykh sudov smeshannogo plavaniya $i$ koasterov Morskogo Inzhenernogo Byuro [Renewed lineup of river-sea multipurpose drycargo vessels and coasters of Marine Engineering Bureau]. Morskaya Birzha (Maritime Market), 3 (37), 38-42 [in Russian].

3. Egorov G.V. (2012). Sukhogruznyye suda smeshannogo plavaniya. Perspektivy sushchestvuyushchego flota [River-sea dry-cargo vessels. Perspectives of existing fleet]. Problemu tekhniki (Problems of technique), 2, 3-21 [in Russian].

4. Egorov G.V. (2012). Sukhogruznyye suda v ekonomiki Rossii XXI veka [Dry-cargo vessels in Russian economy in XXI century]. Morskaya Birzha (Maritime Market), 4 (42), 24-34 [in Russian].

5. Egorov G.V., TonyukV.I. (2015). Dvenadtsat' mnogotselevykh sukhogruznykh sudov dedveytom 5500 tonn proyekta 005RSD03 tipa «Rossiyanin» [Twelve multipurpose dry-cargo vessels of 5500 DWT of 005RSD03 project of «Rossiyanin» type]. Sudostroenie (Shipbuilding), 1, 9-17 [in Russian].

6. (2019). RSD32-2019-507. Formulyar manevrennykh kharakteristik golovnogo sukhogruznogo sudna «NAVIS-1» proyekta RSD32M [Booklet of maneuvering characteristics of head dry-cargo vessel «NAVIS-1》 of RSD32M project]. Nizhniy Novgorod: Astra, 44 (in Russian). 